\title{
Article \\ Soilless System with Supplementary LED Light to Obtain a High-Quality Out-of-Season Production of Green Beans
}

\author{
Angelo Signore (D), Beniamino Leoni, Onofrio Davide Palmitessa *(D) and Pietro Santamaria (D) \\ Department of Agricultural and Environmental Science, University of Bari Aldo Moro, via Amendola 165/A, \\ 70126 Bari, Italy; angelo.signore@uniba.it (A.S.); beniamino.leoni@uniba.it (B.L.); pietro.santamaria@uniba.it (P.S.) \\ * Correspondence: onofrio.palmitessa@uniba.it
}

Citation: Signore, A.; Leoni, B.; Palmitessa, O.D.; Santamaria, P. Soilless System with Supplementary LED Light to Obtain a High-Quality Out-of-Season Production of Green Beans. Agronomy 2021, 11, 1999. https://doi.org/10.3390/ agronomy11101999

Academic Editor: Sara Di Lonardo

Received: 2 September 2021

Accepted: 29 September 2021

Published: 1 October 2021

Publisher's Note: MDPI stays neutral with regard to jurisdictional claims in published maps and institutional affiliations.

Copyright: (c) 2021 by the authors. Licensee MDPI, Basel, Switzerland. This article is an open access article distributed under the terms and conditions of the Creative Commons Attribution (CC BY) license (https:/ / creativecommons.org/licenses/by/ $4.0 /)$.

\begin{abstract}
Green bean (Phaseolus vulgaris L.) is one of the most important sources of vegetable proteins in the world and it is cultivated all year round, but the light availability, during the dark season, limited its growth. Nevertheless, recent studies conducted on greenhouse horticulture demonstrated that, with the application of light emitting diodes (LEDs) as supplementary light (SL) technology, it is possible to overcome this limitation. Consequently, during the experiment conducted, two cultivars of green bean ('Saporro' and 'Maestrale') were grown with a soilless system in a cold greenhouse during the fall-winter period. To increase the photoperiod and the daily light integral (DLI), early in the morning, four hours of red $(R)$, blue $(B)$ and red+blue $(R+B)$ supplementary light were supplied by LEDs at $180 \mu \mathrm{mol} \cdot \mathrm{m}^{-2} \cdot \mathrm{s}^{-1}$ (PPFD) at plants level. Plants grown under LEDs improved the yield and the gas exchange system compared with the plants grown under natural light; when B light was supplied as a sole source of SL, it increased the dry matter content and the brightness ( $\left.\mathrm{L}^{*}\right)$ of the pods. Between the cultivars, 'Maestrale' produced $20 \mathrm{~g} \cdot \mathrm{plant}^{-1}$ of pods more than 'Saporro' but the latter's colour was brighter $\left(\mathrm{L}^{*}\right)$ and greener $\left(\mathrm{a}^{*}\right)$, and 'Saporro' also showed the highest photosynthetic efficiency (ФPSII). In conclusion, 'Maestrale' and 'Saporro' obtained encouraging out-of-season yields under different LED spectra, but among those B light seems to improve overall crop performances and pods quality.
\end{abstract}

Keywords: plant physiology; fluorescence; photosynthesis; greenhouse; gas exchange; pods

\section{Introduction}

Green bean (Phaseolus vulgaris L.) is the most consumed grain legume in the world and has an important role in human diet, due to its high protein and mineral content [1]. For such reason, and because it gets high prices on the market, it is cultivated all year round, usually in greenhouses. However, light intensity for green bean cultivation may be limiting sometimes in greenhouses, particularly in the fall and winter seasons, especially at the northernmost latitudes. The light scarcity may represent a heavy constraint to its cultivation, resulting in a lower yield or in the impossibility to cultivate green beans in the fall and winter, since light plays a fundamental role in plant growth and development processes, which are regulated by light quality (intensity, wavelength), its quantity (fluence rate) and the photoperiod [2]. Until few years ago, supplemental light (SL) was proposed (and used) merely to provide light energy for photosynthesis, most of the time considering a priority high fluence rate, to provide the photosynthetic photon flux density (PPFD), and low-cost operation [2], using conventional light sources, especially fluorescent, metal halide, high-pressure sodium (HPS), and incandescent lamps for cultivating plants indoors [3,4]. However, such lamps, particularly HPS ones, were reported to be not economically feasible [5] and sometimes to have technical limitations. For example, the emissions of HPS, in some phases of plant growth, are different from those emitted by sunlight and from the values required for photosynthesis, both in terms of spectrum and energy $[5,6]$.

In the latest years, the horticultural sector shifted its attention toward light-emitting diodes (LED) as, compared to traditional fluorescent or HPS lamps, it may reduce the 
energy costs due to their higher efficiency, in addition to other advantages such as longer lifetime, lower heat emission, a smaller volume/weight [7] and the possibility to be placed close to the leaves in interlighting and intracanopy irradiation [6]. Furthermore, LEDs allow to manipulate the spectral composition of light and to use the individual spectra of which the visible light is composed [8]. All these aspects, individually or altogether, have shifted the interest of growers from traditional HPS and fluorescent lamps to LED lights [9].

Recently, the use of LEDs as a source of SL has been proposed even in the Mediterranean regions of Europe [10,11], as it may increase the production, improve quality, and allow indoor cultivation if natural light is insufficient, thus ultimately increasing the performance of greenhouse crops. Furthermore, the efficiency of LED installation is also related to the spectra used and, eventually, on their mix: for example, some Authors reported a positive effect of the addition of LED lights to the fluorescent lamps instead of using a monochromatic spectrum [12], while others observed that some wavelengths may improve the nutritional characteristics of vegetables at different stages [13-16] and microgreens [17-19], and may even help to reduce some anti-nutritional compounds, including nitrates [20-22]. Attested that red photons drive photosynthesis more efficiently than blue photons [23], the fundamental role of red:blue spectra on light/plants interaction has been demonstrated [9]. For instance, during an experiment conducted by Izzo et al. [24] on tomato plants, the blue LED light supplied alone caused a reduction of internode length, hypocotyl length, and cotyledon area compared with the plants grown under red spectrum alone and red + blue LEDs. Moreover, the plants grown under blue LEDs alone showed the highest leaf mass per area and, together with the plants grown under red + blue LEDs, had the best maximal photochemical efficiency. In fact, Naznin et al. [25] studied the effect of several red:blue ratios on lettuce, and their results indicate that a certain percentage of blue light is essential with red light to enhance growth and other important parameters such as pigment content and antioxidant capacity; furthermore, the percentage of blue:red light is plant species dependent. The importance of blue light on plant development, photosynthetic apparatus, and chloroplast ultrastructure has been pointed out especially for tomatoes [26] and cucumbers [27].

However, different species may behave in different ways with respect to utilized spectra, thus species-specific studies are needed to tailor the LED spectra to species and growers' needs.

Furthermore, the soilless systems are considered a fundamental technological improvement for modern greenhouse due to its advantages. The independence from the soil as a rooting medium in soilless culture system enables optimization of both physical and chemical characteristics in the root environment and a more efficient control of pathogens without the need to apply soil fumigation. As a result, higher yields at a reasonable production cost with minimal use of pesticides and high product quality can be attained [28].

Starting from the above premises, we have investigated the role of some monochromatic spectra, namely blue $(450 \mathrm{~nm})$, red $(660 \mathrm{~nm})$, and blue plus red, on the production of green beans with a soilless technique and the effects on some morphological and physiological parameters of the plant and the pods.

\section{Materials and Methods}

\subsection{Experimental Set-Up}

An experimental trial was conducted inside an unheated greenhouse located at the Department of Agricultural and Environmental Science (Bari, Italy-41 $06^{\prime} 39.9^{\prime \prime} \mathrm{N} 16^{\circ} 52^{\prime} 53.8^{\prime \prime} \mathrm{E}$ ) in an unheated polymethacrylate greenhouse with a maximum height of $4.5 \mathrm{~m}$.

\subsection{Plant Material and Growing Condition}

Green bean seeds [Phaseolus vulgaris L., cv. Maestrale and 'Saporro' F1 (Seminis)] were sown on 4 September into 4.5 litres plastic pots $(\varnothing 19 \times \mathrm{h} 21 \mathrm{~cm})$ filled with peat (Brill 3 Special, Brill Substrates, Georgsdorf, Germany) enriched with Osmocote Bloom 
$\left(2 \mathrm{~g} \cdot \mathrm{L}^{-1}\right)$ e Osmocote Calmag $\left(1 \mathrm{~g} \cdot \mathrm{L}^{-1}\right)$. The pots were placed on benches $(248 \mathrm{~cm}$ length and $118 \mathrm{~cm}$ width) at a density of 11 plants $\mathrm{m}^{-2}$. The irrigation was done by means of an ebb-and-flow system twice a day, filling the ebb and flow up to $4 \mathrm{~cm}$, using only water and crop consumption was measured by means of a litre counter. The climatic parameter (average of temperature and relative humidity) values inside the greenhouse, as well as the PAR trend, are reported in Figure 1.

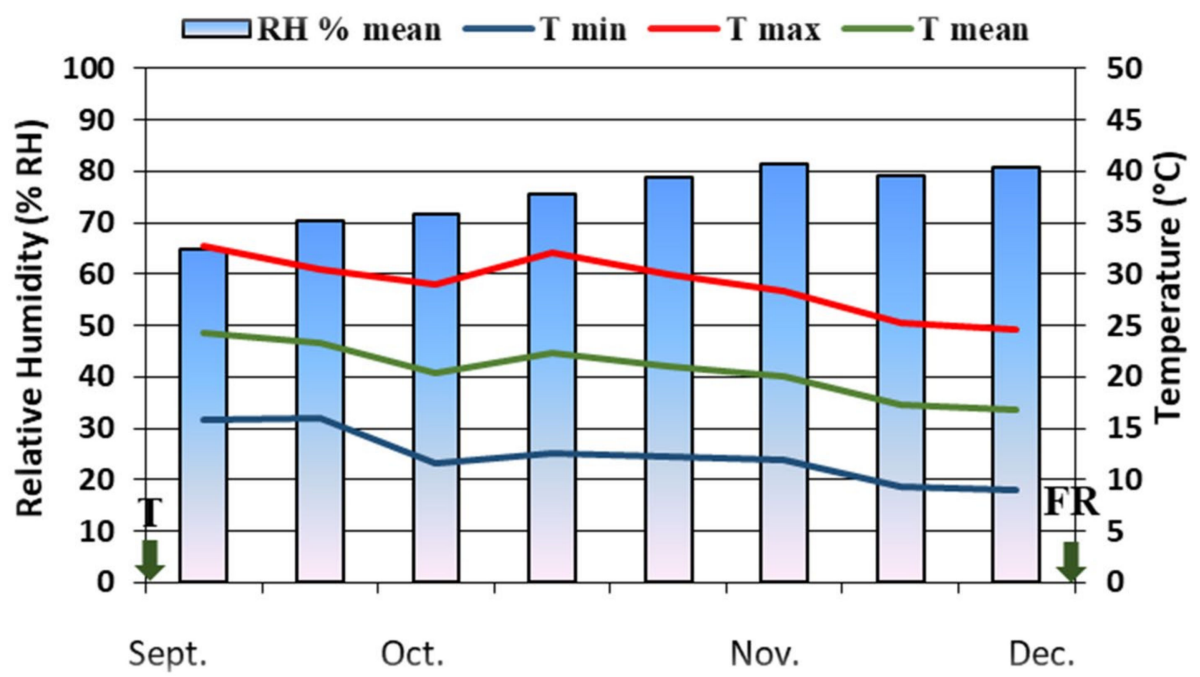

Figure 1. Temperature and relative humidity in the greenhouse during the crop cycle.

\subsection{Supplementary Light Treatments}

The trial consisted of four light treatments, namely sunlight alone or "natural light" (C-control) and three additional lighting by using toplight LED fixtures ['GreenHouse Toplight' C-Led, Imola (BO) - Italy]. The additional light treatments, which started on 19 September, were the following: R $(100 \%$ red light $-660 \mathrm{~nm}), B(100 \%$ blue light $-450 \mathrm{~nm})$ and $\mathrm{R}+\mathrm{B}(50 \%$ red $+50 \%$ blue). The additional photosynthetic photon flux density (PPFD) provided by LEDs was set at canopy level to $180 \mu \mathrm{mol} \cdot \mathrm{m}^{-2} \cdot \mathrm{s}^{-1}$ and was measured with the light meter Li-250 (Li-COR, Lincoln, Nebraska-USA). To set the same light intensity at canopy level for the different light spectra, during a night before the transplant, the light meter Li-250 (Li-COR, Lincoln, Nebraska-USA) was placed at plants level to measure the PPFD of each LED, and the distance between plants level and LEDs module was regulated to guarantee a fixed PPFD of $180 \mu \mathrm{mol} \cdot \mathrm{m}^{-2} \cdot \mathrm{s}^{-1}$. According to plants growth, the LED fixtures were placed on height-adjustable supports, which were adjusted, once a week. The LED fixtures were turned on between 4 and 8 a.m. (when the sunlight intensity at plant level reached $150 \mu \mathrm{mol} \cdot \mathrm{m}^{-2} \cdot \mathrm{s}^{-1}$ ) to ensure four hours of extra illumination at the beginning of the day. The experimental unit (8 plants per cultivar per light spectrum) were arranged in a randomized block design with three replications.

\subsection{Growth Analysis, Yield, Fruit Dry Weight, and Physiological Parameters}

The harvest, on alternate days, started on 2 November and lasted until 11 December. Apart from yield, divided for every harvest in total, fresh, and dry weight of the pods, the colour of the pods was measured with a colorimeter (Chroma Meter CR-400, Konica Minolta, Osaka, Japan).

Physiological measurements were made on the fully expanded and exposed at natural and artificial radiation leaf. They included (I) the content of chlorophyll by means of a MC-100 Chlorophyll Concentration Meter (Apogee Instruments, Logan UT-USA); (II) the chlorophyll fluorescence, which was measured with the PAM-2500 (Walz GmbHEffeltrich, Germany); and (III) photosynthesis and transpiration parameters, which were measured with the LICOR 6400-XT (LI-COR Biosciences, Lincoln, NE, USA). The measurements with LICOR 6400-XT were made with a transparent cuvette (enclosed leaf area: 
$6 \mathrm{~cm}^{2}$ ), setting $400 \pm 1.3 \mu$ bar $\mathrm{CO}_{2}, 22.4 \pm 0.2{ }^{\circ} \mathrm{C}$ cuvette temperature, $70 \pm 1 \% \mathrm{RH}$ and a flow rate of $500 \mu \mathrm{mol} \mathrm{s}^{-1}$. After they had reached stability, $g s$ and $E$ were logged 10 times at $30 \mathrm{~s}$ intervals (to be sure we logged a representative value).

\subsection{Statistical Analysis}

The statistical analysis was performed with the Statistical Analysis System software using the General Linear Model (GLM Proc; SAS 9.1; SAS Institute, Cary, NC, USA).

The experimental factors (LEDs and cultivar) were fixed in a two-way analysis of variance (ANOVA), while the technique of orthogonal contrasts was used to establish differences between light means (three contrasts): (I) Control vs. LEDs; (II) R vs. (B and R + B); (III) B vs. R + B.

\section{Results}

\subsection{Yield, Morphological Parameters, and Colour of Leaves and Pods}

The plants with supplementary LED lighting produced, on average, $19 \%$ more than the control, without showing significant differences between spectra (Table 1). The production was also influenced by the cultivar, as 'Maestrale' produced almost $20 \mathrm{~g} /$ plant more than 'Saporro' (Table 1). Similarly, the cultivar influenced the number of pods per plant and the leaf area, with 'Maestrale' scoring better results than 'Saporro' (Table 1). The height of the plants was modulated by the light, with the plants under LEDs that were higher than those of the control ( $3 \mathrm{~cm}$ on average-Table 1$)$. The dry matter was influenced by both the light treatment and the cultivars, and from their interaction (Table 1). More specifically, the $\mathrm{R}+\mathrm{B}$ treatments decreased by $11 \%$ the dry matter percentage in 'Maestrale' with respect to 'Saporro' (Figure 2).

Table 1. Effects of light spectra and cultivar on fresh weight, number and dry matter percentage of pods, height, number of leaves, and leaf area of green beans.

\begin{tabular}{|c|c|c|c|c|c|c|}
\hline & $\begin{array}{c}\text { Fresh } \\
\text { Weight }\end{array}$ & Number & Height & Leaves & $\begin{array}{l}\text { Leaf } \\
\text { Area }\end{array}$ & $\begin{array}{c}\text { Dry } \\
\text { Matter }\end{array}$ \\
\hline & g.Plant ${ }^{-1}$ & n. $\cdot$ Plant $^{-1}$ & $\mathrm{~cm}$ & n. & $\mathrm{cm}^{2}$ & $\begin{array}{c}\mathrm{g} \cdot 100 \mathrm{~g}^{-1} \\
\text { Fresh } \\
\text { Weight }\end{array}$ \\
\hline \multicolumn{7}{|l|}{ Light (L) } \\
\hline Blue (B) & 154.5 & 76.4 & 53.35 & 27.5 & 4141 & 8.45 \\
\hline Red + Blue $(\mathrm{R}+\mathrm{B})$ & 140.0 & 70.7 & 54.27 & 26.7 & 4368 & 8.07 \\
\hline Red (R) & 141.9 & 70.3 & 54.33 & 26.5 & 4372 & 8.45 \\
\hline Control (C) & 122.5 & 66.5 & 51.02 & 25.3 & 3982 & 8.46 \\
\hline \multicolumn{7}{|l|}{ Cultivar (Cv) } \\
\hline Maestrale & 149.2 & 73.6 & 54.63 & 27.58 & 4546 & 8.20 \\
\hline Saporro & 130.3 & 68.4 & 51.85 & 25.42 & 3885 & 8.51 \\
\hline \multicolumn{7}{|l|}{ Significance $^{1}$} \\
\hline C vs. LED & * & ns & * & ns & ns & ns \\
\hline B vs. $(R, R+B)$ & ns & ns & ns & ns & ns & * \\
\hline R vs. $R+B$ & ns & ns & ns & ns & ns & $* *$ \\
\hline $\mathrm{Cv}$ & $* *$ & $*$ & ns & ns & * & * \\
\hline$(\mathrm{C}$ vs. $\mathrm{LED}) \times \mathrm{Cv}$ & ns & ns & ns & ns & ns & ns \\
\hline$[\mathrm{B}$ vs. $(\mathrm{R}, \mathrm{R}+\mathrm{B})] \times \mathrm{Cv}$ & ns & ns & ns & ns & ns & ns \\
\hline$(\mathrm{R}$ vs. $\mathrm{R}+\mathrm{B}) \times \mathrm{Cv}$ & ns & ns & ns & ns & ns & $* *$ \\
\hline
\end{tabular}

${ }^{1}$ Significance of F: $\mathrm{ns}=$ not significant for $p \leq 0.05 ;{ }^{*}=$ significant for $p \leq 0.05$ and ${ }^{* *}$ significant for $p \leq 0.01$. 


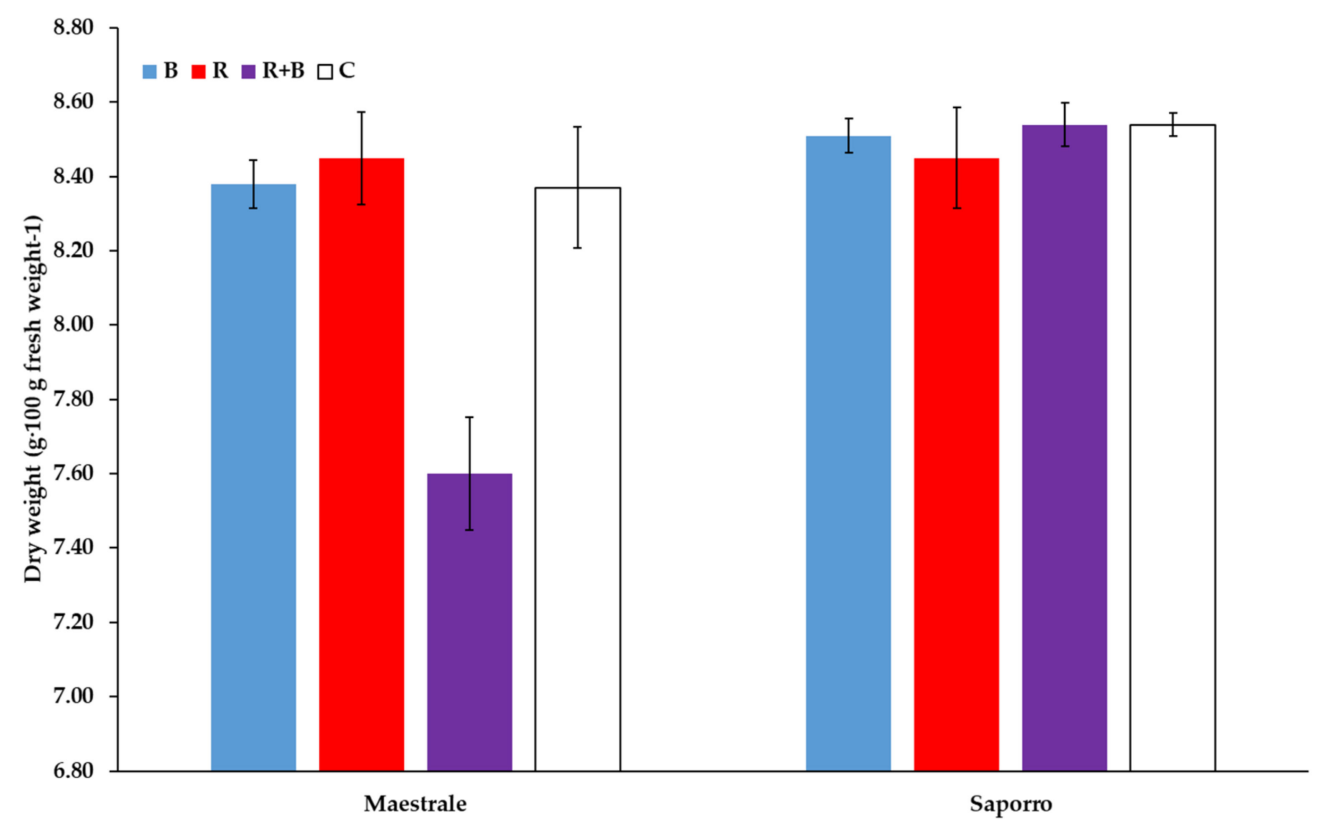

Figure 2. Dry matter content of green bean pods as influenced by interactions between cultivars and light spectra. Vertical bars represent the standard error of mean values.

Considering the colour of the pods, 'Saporro' produced pods with a lightness $\left(L^{*}\right) 9 \%$ higher than those obtained from 'Maestrale' (Table 2). Furthermore, 'Saporro' had pods greener $\left(\mathrm{a}^{*}\right)$ and more yellow $\left(\mathrm{b}^{*}\right)$ than 'Maestrale' and consequently the colour saturation (Chroma) was 17\% higher in 'Saporro' compared to 'Maestrale' (Table 2). With regard to the supplemental light effects on the pods' colour, the pods obtained from the plant grown under only blue (B) LEDs had 7\% higher $\mathrm{L}^{*}$ than those harvested from only red (R) and red+blue $(R+B)$ supplemental light treatments, while the Chroma parameter was $3 \%$ lower for the pods harvested under R than R + B LEDs (Table 2). Finally, the hue $\left(\mathrm{h}^{\circ}\right)$ of pods was between 120 and 121 (Table 2). Instead, the colour of the leaves did not vary significantly between the cultivars considered, but it was influenced by the light spectra (Table 3 ). The leaves of the plant grown under $\mathrm{R}$ had greener $(10 \%)$ leaves than plants grown under $\mathrm{R}+\mathrm{B}$, while the leaves of the plants grown under B had less (9\%) yellow fraction than those grown under R and R + B LEDs (Table 3). Still considering the yellow fraction, it was $11 \%$ greater for the leaves grown with $R$ compared to those grown under $R+B$ (Table 3). Contrary to what was shown for $b^{*}$, the leaves grown under B LEDs had a slightly higher hue $(1 \%)$ than the leaves grown under $\mathrm{R}+\mathrm{B}$ but a lower colour saturation ( $8 \%$ ) compared to the leaves grown under $\mathrm{R}$ and $\mathrm{R}+\mathrm{B}$ (Table 3). Finally, the value of Chroma of the leaves was $11 \%$ higher under $\mathrm{R}$ than under $\mathrm{R}+\mathrm{B}$ (Table 3 ). Similar to the trend shown by the colours of the leaves, the chlorophyll content did not vary significantly between the cultivars and its average value was $319 \mu \mathrm{mol} \cdot \mathrm{m}^{-2}$ (Table 3). Instead, the application of LEDs increased by $14 \%$ the chlorophyll content of the leaves compared with natural light conditions and the leaves of the plants grown under B LEDs had 16\% more chlorophyll content than those grown under R and R + B supplemental light spectra (Table 3). 
Table 2. Effects of the light spectra and cultivar on the colour parameters of pods harvested on 4 November 2020.

\begin{tabular}{|c|c|c|c|c|c|}
\hline & $\mathbf{L}^{*}$ & $a^{*}$ & $\mathbf{b}^{*}$ & $\mathbf{h}^{\circ}$ & C \\
\hline & $(0-100)$ & $(-60 /+60)$ & $(-60 /+60)$ & $\sqrt{ }\left(a^{2}+b^{2}\right)$ & $(0-360)^{\circ}$ \\
\hline \multicolumn{6}{|l|}{ Light (L) } \\
\hline Blue (B) & 42.70 & -15.35 & 25.92 & 120.66 & 31.28 \\
\hline Red + Blue $(\mathrm{R}+\mathrm{B})$ & 40.37 & -15.29 & 26.02 & 120.53 & 30.12 \\
\hline $\operatorname{Red}(\mathrm{R})$ & 39.18 & -14.69 & 25.28 & 120.20 & 29.24 \\
\hline Control (C) & 41.34 & -15.81 & 26.39 & 120.93 & 30.76 \\
\hline \multicolumn{6}{|l|}{ Cultivar (Cv) } \\
\hline Maestrale & 39.10 & -14.77 & 25.02 & 120.61 & 26.60 \\
\hline Saporro & 42.69 & -15.80 & 26.78 & 120.54 & 31.10 \\
\hline \multicolumn{6}{|l|}{ Significance ${ }^{1}$} \\
\hline C vs. LED & ns & ns & ns & ns & ns \\
\hline$B$ vs. $(R, R+B)$ & $* *$ & ns & ns & ns & ns \\
\hline$R$ vs. $R+B$ & ns & ns & ns & ns & * \\
\hline $\mathrm{Cv}$ & $*$ & $* *$ & $*$ & ns & * \\
\hline$(\mathrm{C}$ vs. $\mathrm{LED}) \times \mathrm{Cv}$ & ns & ns & ns & ns & ns \\
\hline$[B$ vs. $(R, R+B)] \times C v$ & ns & ns & ns & ns & ns \\
\hline$(\mathrm{R}$ vs. $\mathrm{R}+\mathrm{B}) \times \mathrm{Cv}$ & ns & ns & ns & ns & ns \\
\hline
\end{tabular}

${ }^{1}$ Significance of $\mathrm{F}: \mathrm{ns}=$ not significant for $p \leq 0.05{ }^{*}=$ significant for $p \leq 0.05$ and ${ }^{* *}$ significant for $p \leq 0.01$.

Table 3. Effects of light spectra and cultivar on colour parameters and chlorophyll content of leaves of green beans measured on 4 November 2020.

\begin{tabular}{|c|c|c|c|c|c|c|}
\hline & $\mathbf{L}^{*}$ & $a^{*}$ & $\mathbf{b}^{*}$ & $\mathbf{h}^{\circ}$ & $\mathrm{C}$ & $\begin{array}{c}\text { Chlorophyll } \\
\text { Content }\end{array}$ \\
\hline & $(0-100)$ & $(-60 /+60)$ & $(-60 /+60)$ & $\sqrt{ }\left(a^{2}+b^{2}\right)$ & $(0-360)^{\circ}$ & $\mu \mathrm{mol} \cdot \mathrm{m}^{-2}$ \\
\hline \multicolumn{7}{|l|}{ Light (L) } \\
\hline Blue (B) & 35.79 & 363 & -12.57 & 14.16 & 131.69 & 18.94 \\
\hline Red + Blue $(R+B)$ & 36.12 & 318 & -12.70 & 14.72 & 130.80 & 19.44 \\
\hline Red (R) & 37.13 & 305 & -14.02 & 16.41 & 130.53 & 21.59 \\
\hline Control (C) & 35.92 & 289 & -13.29 & 15.08 & 131.39 & 20.10 \\
\hline \multicolumn{7}{|l|}{ Cultivar (Cv) } \\
\hline Maestrale & 36.98 & 325 & -12.91 & 14.80 & 131.15 & 16.64 \\
\hline Saporro & 36.49 & 313 & -13.38 & 15.39 & 131.06 & 20.39 \\
\hline \multicolumn{7}{|l|}{ Significance ${ }^{1}$} \\
\hline C vs. LED & ns & * & ns & ns & ns & ns \\
\hline$B$ vs. $(R, R+B)$ & ns & * & ns & $*$ & $*$ & $*$ \\
\hline R vs. $R+B$ & ns & ns & $*$ & * & ns & * \\
\hline $\mathrm{CV}$ & ns & ns & ns & ns & ns & ns \\
\hline$(\mathrm{C}$ vs. $\mathrm{LED}) \times \mathrm{Cv}$ & ns & ns & ns & ns & ns & ns \\
\hline$[B$ vs. $(R, R+B)] \times C v$ & ns & ns & ns & ns & ns & ns \\
\hline$(\mathrm{R}$ vs. $\mathrm{R}+\mathrm{B}) \times \mathrm{Cv}$ & ns & ns & ns & ns & ns & ns \\
\hline
\end{tabular}

${ }^{1}$ Significance of $\mathrm{F}: \mathrm{ns}=$ not significant for $p \leq 0.05 ;{ }^{*}=$ significant for $p \leq 0.05$.

\subsection{Physiological Parameters: Photosynthesis, Chlorophyll Content, and Chlorophyll Fluorescence}

LEDs used as supplementary light improved the gas exchange parameters of the green bean plants (Table 4). In fact, the net photosynthetic rate increased by $20 \%$ when the plants were grown under LEDs, compared to the plants grown under control light conditions (Table 4). At the same time, for the plants grown under LEDs, stomatal conductance and transpiration rate were respectively $60 \%$ and $55 \%$ higher than for the plants grown without supplemental light (Table 4). Generally, the plants grown under LEDs showed 6\% higher leaf temperature than the plants grown only with natural light and, among the plants grown under LEDs, those cultivated with $\mathrm{R}+\mathrm{B}$ and $\mathrm{R}$ LEDs had higher leaf temperature than the plants grown under B (Table 4). Furthermore, when 'Maestrale' was grown with B LEDs, it showed 66\% lower stomatal conductance compared with the same cultivar grown under R and R + B supplemental light (Figure 3A); conversely, the gs of 'Saporro' grown under B was more than twice higher than under R and R + B LEDs (Figure 3A). The same trend described for $g s$ was observed for the transpiration rate (Figure 3B). Moreover, the leaf temperature of 'Maestrale' did not vary significantly under LEDs and control 
conditions (22.3 vs. $22.6{ }^{\circ} \mathrm{C}$ ) but for 'Saporro' it was almost $3.0^{\circ} \mathrm{C}$ higher under LEDs than under control ( 24.7 vs. $21.7^{\circ} \mathrm{C}$; Figure 3C). In detail, 'Saporro' showed the highest leaf temperature under R and R + B LEDs (Figure 3C). Finally, for 'Maestrale', the water uses efficiency (WUE), expressed as $\mu \mathrm{mol}$ of $\mathrm{CO}_{2}$ fixed for mmol of $\mathrm{H}_{2} \mathrm{O}$ transpired, was $24 \%$ higher under LEDs than under control, while for 'Saporro' the highest WUE was found for the plants grown under B: almost 33\% higher than under R and R + B LEDs (Figure 3D).

During this experiment, the average value of $\mathrm{F}$ of the two green bean cultivars considered through the different light conditions was 0.560 (Table 5). While the fraction of absorbed photons that were used for photochemistry in a light adapted green bean leaf (ФPSII) was 6.5\% higher for 'Saporro' than 'Maestrale' (Table 5). The minimal fluorescence $\left(\mathrm{F}_{0}{ }^{\prime}\right)$ was 0.375 , while the maximum chlorophyll fluorescence $\left(\mathrm{F}_{\mathrm{m}}{ }^{\prime}\right)$ in the light adapted state was $7.7 \%$ higher for the green bean plants grown under B LEDs than under R and R $+B$ (Table 5). Furthermore, the quantum energy used for the photosynthesis and photorespiration (qP, photochemical quenching,) was on average 0.743 , while the non-photochemical quenching (NPQ) was on average 0.488 (Table 5). Finally, considering a dark-adapted leaf, the fraction of absorbed photons that was used for chemistry $\left(\mathrm{F}_{\mathrm{v}} / \mathrm{F}_{\mathrm{m}}\right)$ was 0.775 with any variation between the light treatments and between the cultivars (Table 5).

Table 4. Effects of light spectra and cultivar on photosynthesis rate $(A)$, stomatal conductance $(g s)$, transpiration rate $(E)$, leaf temperature (Leaf T) and water use efficiency (WUE) of green beans measured on 6 November 2020.

\begin{tabular}{|c|c|c|c|c|c|}
\hline & $A$ & $g s$ & $E$ & Leaf $\mathrm{T}$ & WUE \\
\hline & $\begin{array}{c}\mu \mathrm{mol} \\
\mathrm{CO}_{2} \cdot \mathrm{m}^{2} \mathrm{~s}^{-1}\end{array}$ & $\begin{array}{c}\mu \mathrm{mol} \\
\mathrm{H}_{2} \mathrm{O} \cdot \mathrm{m}^{2} \mathrm{~s}^{-1}\end{array}$ & $\begin{array}{c}\text { mmol } \\
\mathrm{H}_{2} \mathrm{O} \cdot \mathrm{m}^{2} \mathrm{~s}^{-1}\end{array}$ & ${ }^{\circ} \mathrm{C}$ & $A / g s$ \\
\hline \multicolumn{6}{|l|}{ Light (L) } \\
\hline Blue (B) & 13.4 & 0.153 & 1.83 & 22.26 & 0.082 \\
\hline Red + Blue $(\mathrm{R}+\mathrm{B})$ & 13.5 & 0.149 & 2.09 & 24.26 & 0.071 \\
\hline $\operatorname{Red}(\mathrm{R})$ & 13.3 & 0.116 & 1.62 & 23.97 & 0.070 \\
\hline Control (C) & 11.1 & 0.087 & 1.19 & 22.13 & 0.070 \\
\hline \multicolumn{6}{|l|}{ Cultivar (Cv) } \\
\hline Maestrale & 12.3 & 0.113 & 1.45 & 22.37 & 0.075 \\
\hline Saporro & 13.4 & 0.140 & 1.91 & 23.93 & 0.072 \\
\hline \multicolumn{6}{|l|}{ Significance ${ }^{1}$} \\
\hline C vs. LED & * & * & $* *$ & $* *$ & ns \\
\hline B vs. $(R, R+B)$ & ns & ns & ns & ns & $*$ \\
\hline R vs. $R+B$ & ns & ns & ns & $* *$ & ns \\
\hline $\mathrm{Cv}$ & ns & ns & ns & $* * *$ & ns \\
\hline$(\mathrm{C}$ vs. $\mathrm{LED}) \times \mathrm{Cv}$ & ns & ns & ns & $* * *$ & * \\
\hline$[\mathrm{B}$ vs. $(\mathrm{R}, \mathrm{R} \times \mathrm{B})] \times \mathrm{Cv}$ & ns & * & * & ns & * \\
\hline$(\mathrm{R}$ vs. $\mathrm{R}+\mathrm{B}) \times \mathrm{C}$ v & ns & ns & ns & $* *$ & ns \\
\hline
\end{tabular}



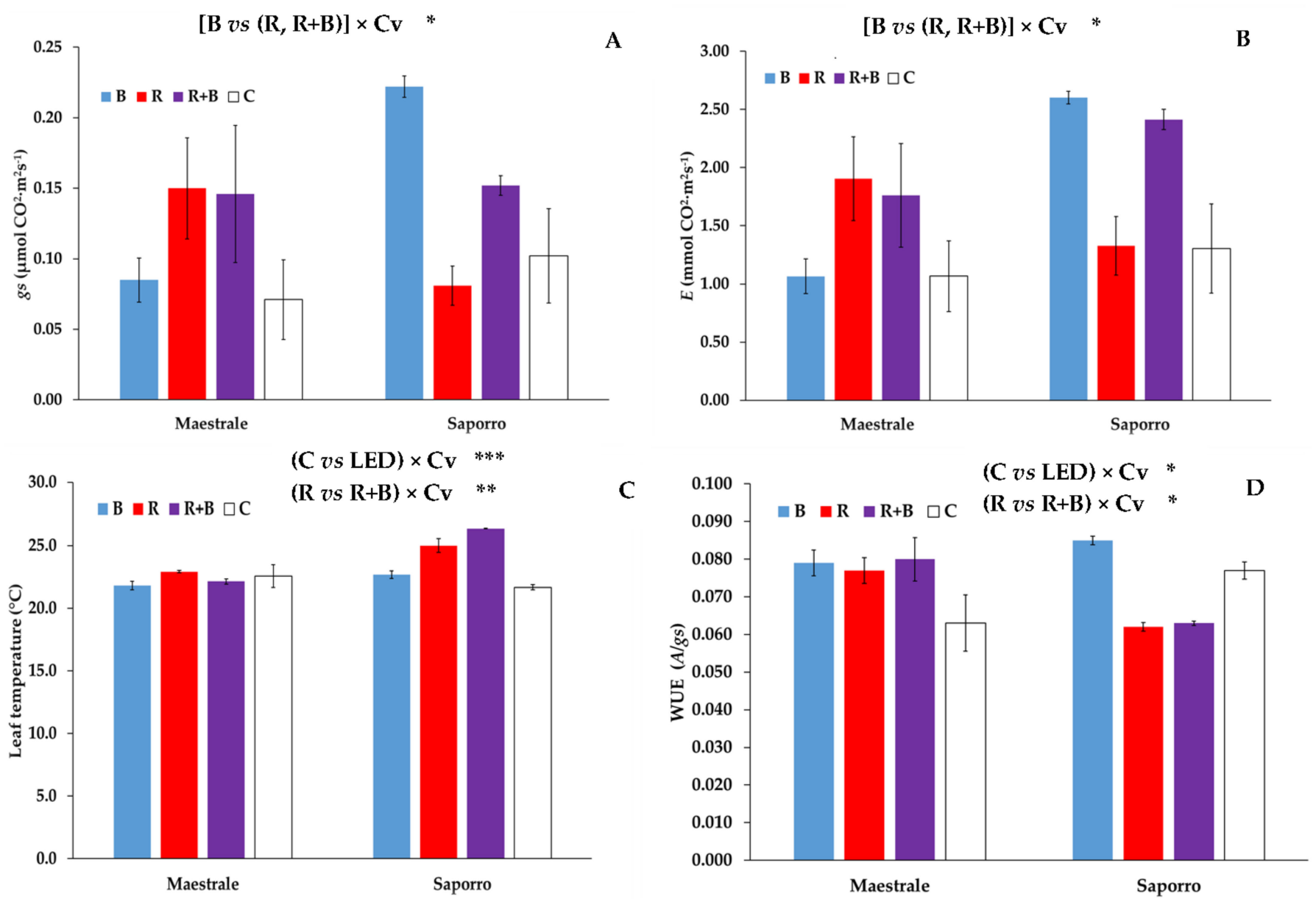

Figure 3. Stomatal conductance $(g s ; \mathbf{A})$, transpiration rate $(E ; \mathbf{B})$; leaf temperature $(\mathbf{C})$ and water use efficiency (WUE; D) of green bean pods as influenced by interactions between cultivars and light spectra. Vertical bars represent the standard error of mean values. Significance: ${ }^{*}=$ significant for $p \leq 0.05$; ${ }^{* *}$ significant for $p \leq 0.01$ and ${ }^{* *}$ significant for $p \leq 0.001$.

Table 5. Effects of light spectra and cultivar on chlorophyll fluorescence parameters of leaves of green bean.

\begin{tabular}{|c|c|c|c|c|c|c|c|}
\hline & $F$ & $\mathrm{~F}_{0}^{\prime}$ & $F_{m}^{\prime}$ & ФPSII & NPQ & $\mathrm{qP}$ & $F_{v} / F_{m}$ \\
\hline \multicolumn{8}{|l|}{ Light (L) } \\
\hline Blue (B) & 0.544 & 0.371 & 1.154 & 0.528 & 0.356 & 0.779 & 0.771 \\
\hline Red + Blue $(\mathrm{R}+\mathrm{B})$ & 0.570 & 0.382 & 1.132 & 0.495 & 0.483 & 0.752 & 0.769 \\
\hline $\operatorname{Red}(\mathrm{R})$ & 0.542 & 0.366 & 1.010 & 0.453 & 0.637 & 0.733 & 0.775 \\
\hline Control (C) & 0.582 & 0.380 & 1.135 & 0.488 & 0.476 & 0.709 & 0.786 \\
\hline \multicolumn{8}{|l|}{ Cultivar (Cv) } \\
\hline Maestral & 0.559 & 0.378 & 1.076 & 0.476 & 0.537 & 0.733 & 0.768 \\
\hline Saporro & 0.560 & 0.372 & 1.114 & 0.507 & 0.439 & 0.753 & 0.783 \\
\hline \multicolumn{8}{|l|}{ Significance $^{1}$} \\
\hline C vs. LED & ns & ns & ns & ns & ns & ns & ns \\
\hline B vs. $(R, R+B)$ & ns & ns & * & ns & ns & ns & ns \\
\hline R vs. $R+B$ & ns & ns & ns & ns & ns & ns & ns \\
\hline $\mathrm{Cv}$ & ns & ns & ns & $*$ & ns & ns & ns \\
\hline$(\mathrm{C}$ vs. $\mathrm{LED}) \times \mathrm{Cv}$ & ns & ns & ns & ns & ns & ns & ns \\
\hline$[\mathrm{B}$ vs. $(\mathrm{R}, \mathrm{R}+\mathrm{B})] \times \mathrm{Cv}$ & ns & ns & ns & ns & ns & ns & ns \\
\hline$(\mathrm{R}$ vs. $\mathrm{R}+\mathrm{B}) \times \mathrm{Cv}$ & ns & ns & ns & ns & ns & ns & ns \\
\hline
\end{tabular}

${ }^{1}$ Significance of F: $\mathrm{ns}=$ not significant for $p \leq 0.05 ;{ }^{*}=$ significant for $p \leq 0.05$.

\section{Discussion}

During this research activity we assessed the growth behaviour and the physiological performances of two cultivars of green bean (Phaseolus vulgaris L.) grown in a soilless system 
during the fall-winter season, under different SL spectra supplied with LED modules. Phaseolus vulgaris L. or beans (which include many genotypes) are recognized as the second most important source of human dietary protein [29] and for this reason it is important to improve the yield and the nutritional values of the pods. The genotypes, the growth environmental conditions, and the cropping system influence the growth and physiological performances of this crop [30].

Nowadays, green beans are cultivated worldwide from $52^{\circ} \mathrm{N}$ to $32^{\circ} \mathrm{S}$ of latitude [30], especially during the sunniest and hottest seasons, because low light intensity, low photoperiod, and low temperatures reduce crop performance. In the regions of Southern Italy green beans are mostly cultivated during the spring-summer period in the open field, but to obtain the out-of-season production it is necessary to resort to greenhouse cultivation. In addition, El Youssfi et al. [31] found that, using a soilless system technique, it is possible to obtain a yield comparable (or higher) to that obtained with traditional techniques ( $22 \mathrm{t} \cdot \mathrm{ha}^{-1}$ on average). Furthermore, the recent achievement regarding the development of artificial light technologies [32] and their positive effects on crop performances in the Mediterranean regions $[10,11]$ inspired our research activity, applying different SL spectra supplied with LED technology to green bean cultivation. As was shown on Table 1, the results were encouraging, because the green bean plants grown under LEDs produced $16 \%$ more edible product than under natural light conditions, but the number of the pods did not vary between light conditions (Table 1). Furthermore, LEDs supplied a total light integral (TLI; sum of daily light integrals) of $62 \mathrm{~mol} \cdot \mathrm{m}^{-2}$, while the TLI of sun radiation at plants level was $605 \mathrm{~mol} \cdot \mathrm{m}^{-2}$ (data not shown). Hence, the green bean plants grown under LEDs received $10 \%$ more photosynthetic radiation than under natural light conditions and the increase of production was higher than the increase of photosynthetic radiation. Basing on this, it is possible to affirm that the SL application was economically effective. Furthermore, considering the SL treatments, the DW content of pods did not differ significantly: this means that the plants grown under LEDs produced more grams of pods than under natural light, probably because they had a higher water content under LEDs than under control conditions (Table 1). Considering the cultivars, 'Maestrale' obtained the highest yield, producing a greater number of pods than 'Saporro', but with a lower DW (Table 1).

To understand if the production obtained during this experiment is comparable to the green bean production obtained during the spring-summer period with traditional techniques (22 $\mathrm{t} \cdot \mathrm{ha}^{-1}$ on average [31]), the average production per plant under LEDs was considered (145.46 $\mathrm{g}$ of pods per plants; Table 1 ). This value was multiplied by 11 plants $\cdot \mathrm{m}^{-2}$ to obtain the pods production per $\mathrm{m}^{-2}$ and again multiplied by $10^{4}$ to obtain the production per hectare. Finally, during this experiment the plants grown under LEDs obtained an average yield of $16 \mathrm{t} \cdot \mathrm{ha}^{-1}$ that was lower considering the $22 \mathrm{t} \cdot \mathrm{ha}^{-1}$ but acceptable considering that it was obtained during the fall-winter season, a period during which this crop is not cultivated due the suboptimal environmental conditions. Furthermore, the harvesting period during this experiment was only 39 days (from 2 November to 11 December), limiting plant yield. It may be extended by working in a greenhouse with a heating system.

To discuss about the nutritional value of the pods obtained during this experiment, it is important to remember that the optimal protein daily intake for human diet is $0.91 \mathrm{~g}$ of proteins $\cdot \mathrm{kg}^{-1} \cdot \mathrm{day}^{-1}$ [33]. Moreover, the average protein content of green bean pods is $22 \%$ [34] and the average fresh weight of the pods obtained during this experiment was $2 \mathrm{~g}$ (Table 1). To satisfy the protein daily intake of an adult of $80 \mathrm{~kg}$, a person needs to ingest almost $165 \mathrm{~g}$ of green bean pods. Thus, during a winter crop cycle, using soilless system and LEDs as supplemental light technique, the pods production of green bean allowed to satisfy, the $50 \%$ of the optimal proteins daily intake of an adult. It was a great result because the pods of green beans are generally consumed as a side dish, together with other foods (vegetables and meet).

Instead, plant height was a morphological characteristic of the green bean plants influenced by both SL and cultivar treatments (Table 1). Similar to the results obtained by 
Pozzella et al. [7], the green bean plants cultivated under LEDs had higher height than plants grown only with natural light (Table 1). This was due to the fact that light does not only drive photosynthesis but dictates specific signals which regulate plant development, shaping and metabolism, in the complex phenomenon of photomorphogenesis [35]. Previous studies have clearly indicated that at least two photoreceptor systems, phytochromes and cryptochromes, mediate elongation growth [36]. Although both red and blue light may mediate stem elongation [37], under certain light intensities $\left(50-100 \mu \mathrm{mol} \cdot \mathrm{m}^{-2} \cdot \mathrm{s}^{-1}\right.$ PPFD), both red and blue light spectra promoted stem elongation in a shade-avoidance response that varied among the species [36]. Between the cultivars, 'Maestrale' had higher plant height than 'Saporro' and this contributed to the differentiation of a greater number of pods for the first genotype than the second (Table 1). Finally, the total leaf area was not influenced by light treatments, but between the genotypes 'Maestrale' showed the highest leaf area, giving the opportunity to absorb more photosynthetic active radiation to improve the biomass production (Table 1).

Colour is one of the most important quality components of fresh fruit and vegetables [38]. The appearance of a product as judged by its colour can often be used to determine the pigment content of a product, which in turn is often an index of quality [39]. CIELAB colour scale system is commonly used in the food industry and the coordinates $\mathrm{L}^{*}, \mathrm{a}^{*}$ and $b^{*}$ are directly measured [39]. The parameter $\mathrm{a}^{*}$ takes positive values for reddish colours and negative values for the greenish ones; $b^{*}$ takes positive values for yellowish colours and negative values for the bluish ones. $\mathrm{L}^{*}$ is an approximate measurement of luminosity, which is the property according to which each colour can be considered equivalent to a member of the greyscale, between black and white [39]. Chroma $\left(C^{*}\right)$, considered the quantitative attribute of colourfulness, is used to determine the degree of difference of a hue in comparison to a grey colour with the same lightness. The higher the chroma values, the higher is the colour intensity of samples perceived by humans [39]. Hue angle $\left(\mathrm{h}^{*}\right)$, considered as the qualitative attribute of colour, is the attribute according to which colours have been traditionally defined as reddish, greenish, etc., and it is used to define the difference of a certain colour with reference to a grey colour with the same lightness. An angle of $0^{\circ}$ or $360^{\circ}$ represents red hue, whilst angles of $90^{\circ}, 180^{\circ}$, and $270^{\circ}$ represent yellow, green, and blue hues, respectively. It has been extensively used in the evaluation of colour parameters in green vegetables, fruits, and meats [39].

Considering the colour parameters of the pods (Table 2), 'Saporro' exhibited pods with a more intense green colour than 'Maestrale' and this quality trait was observed also through human eyes. This occurrence was reflected in the highest values of $L^{*}, a^{*}, b^{*}$, and $C^{*}$ found in the pods harvested from 'Saporro' (Table 2). Green colours of fruits and vegetables are due to the presence of chlorophyll molecules, mainly chlorophylls a and $b$ : chlorophyll a has an intense blue-green colour, whereas chlorophyll $b$ is characterized by a yellow-green colour [40]. Therefore, the higher value of the $b^{*}$ parameter measured in the pods harvested from 'Saporro' plants (Table 2) indicated that the best colour intensity and hue found in the pods of this genotype could be attributed to a higher content of chlorophyll a. Finally, the effects of SL spectral quality on the colour of the pods were not evidenced at human eyes and the parameters set out in Table 2 demonstrated the low variability between the SL treatments. Probably, the amount of radiation supplied by the sun diluted the effects of LED light spectra on this quality factor. Instead, the colour of the leaf was influenced by the SL spectra, but it did not vary between genotypes (Table 3). The leaves of the green bean plants grown under LEDs had a more intense green colouration than under natural light conditions (Table 3). This was more easily detectable for the leaf grown under R LEDs. In fact, the parameters $a^{*}, b^{*}$, and $C^{*}$ were higher for the leaf of the plant grown under R compared with other light treatment (Table 3). As the leaf colour was greener under LEDs, the leaf chlorophyll content was higher for the plants grown under LEDs than under natural light (Table 2), confirming that both $\mathrm{B}$ and $\mathrm{R}$ light spectra influenced, with different physiological processes, the chlorophyll synthesis and degradation [41]. 
Blue light is involved in a wide range of plant processes such as phototropism, photomorphogenesis, stomatal opening, and leaf photosynthetic functioning [42]. At the chloroplast level, blue light has been associated with the expression of 'sun-type' characteristics such as high photosynthetic capacity, and its enhancement effect on photosynthetic capacity appears to be greater when using combinations of red and blue light produced by LEDs [42]. The results obtained during this experiment confirmed that $R$ and $B$ LEDs supplied as SL alone or in combination with each other increased the gas exchange capability of green bean plants (Table 4). Furthermore, the positive effects of B spectra on stomatal conductance and transpiration rate were particularly detectable in 'Saporro', which showed the highest physiological performances when the plants grew under $B$ or $R+B$ LEDs (Figure 3A,B). However, the gas exchange system influenced other physiological parameters, such as leaf temperature and water use efficiency (Table 4); in fact, Zhenzhu and Guangsheng [43] found that stomatal conductance and transpiration rate were negatively correlated with leaf temperature, while Von Caemmerer and Evans observed that some species showed large increases in stomatal conductance with increasing leaf temperature [44]. These contradictory results are probably due to several other factors that can affect both leaf temperature and stomatal behaviour (environmental conditions, genotypes, cultivation technique, etc.). In fact, during this study the leaf of the plants grown under LEDs had higher leaf temperature than that under control conditions; between the cultivars, 'Saporro' (which showed the highest values of $g s$ and $E$ ) had the highest leaf temperature (Figure 3C). Probably, during our experiment stomatal conductance and transpiration rate were not the main factors responsible for leaf temperature variation, but the plants' architecture and the infra-red radiation supplied by the sun may have influenced this parameter. Finally, the positive effects of LED SL on net photosynthetic rate, stomatal conductance, and transpiration rate improved the water use efficiency of the plant grown under LEDs, with some differences between the cultivars: while 'Maestrale' improved the WUE when the plants grew under B, R and R + B LEDs, 'Saporro' showed this trend only under B (Figure 3D).

Considering the fluorescence parameters, when a quantum of light is absorbed by a molecule of chlorophyll, the energy of the quantum is transferred to the valence electrons of the chlorophyll, raising them to an excited state. The electrons return rapidly to their ground level, releasing the absorbed energy as fluorescence (F), heat, or photosynthetic photochemistry. For all the treatments (light spectra and cultivar) considered during this experiment, $\mathrm{Fv} / \mathrm{Fm}$ were around the optimal value of 0.8 [45] confirming that PSII efficiency was not affected by light spectra variation and genotypes (Table 5). Furthermore, the efficiency of PSII (ФPSII) was not influenced by light treatment but was $6.5 \%$ higher in 'Saporro' than 'Maestrale' (Table 5), and a decrease in ФPSII could indicate an inhibition of the redox reaction after the primary acceptor quinone $(\mathrm{QA})$ with a slowdown in electron transfer between QA and the secondary acceptor (QB; [7]). However, the value of $\Phi P S I I$ found in 'Maestrale' was not raising concerns about the photosynthetic efficiency of the PSII of this genotype [46]. Moreover, the other fluorescence parameters measured in this study $\left(\mathrm{F}, \mathrm{F}_{0}{ }^{\prime}\right.$, NPQ and $\left.\mathrm{qP}\right)$ did not vary between the treatments (Table 4) and only maximum chlorophyll fluorescence $\left(\mathrm{F}_{\mathrm{m}}{ }^{\prime}\right)$, in the light adapted state, was $7.7 \%$ higher under $B$ than under $R$ and $R+B$ (Table 5), probably because when blue light was given alone it contained more energy compared with the other light treatments, causing an increase in this parameter.

\section{Conclusions}

The cultivation of green beans (Phaseolus vulgaris L.) during the fall-winter period in a greenhouse with soilless system and LED modules, used as SL technology, allowed to obtain yields comparable to those obtained with a traditional technique during the spring-summer crop cycle. On the basis of our results, LEDs improve pods production, pods quality, plant morphology, and plant physiology. Considering the LED light spectra applied during the cultivation, blue spectra given alone or in combination with red spectra 
improved the crop performances, but further studies will be conducted in an indoor environment to study the light quality effects on green bean plants, avoiding the effects of sunlight. Finally, the physiological behaviour of the two cultivars considered during the experiment did not vary significantly but 'Maestrale' produced more grams of pods (with a lower quality) than 'Saporro'.

Author Contributions: Conceptualization, A.S., B.L. and O.D.P.; methodology, A.S., B.L. and O.D.P.; validation, A.S. and P.S.; formal analysis, A.S. and P.S.; investigation, A.S. and P.S. resources, P.S.; data curation, A.S. and P.S.; writing—original draft preparation, A.S. and O.D.P.; writing—review and editing, A.S., O.D.P. and P.S.; visualization, A.S., B.L., O.D.P. and P.S.; supervision, A.S. and P.S.; project administration P.S.; funding acquisition P.S. All authors have read and agreed to the published version of the manuscript.

Funding: This research was funded by the Rural Development Programme of the Apulia Region (Italy) 2014-2020, Submeasure 16.2 (Support for pilot projects and the development of new products, practices, processes and technologies, and the transfer and the dissemination of the results obtained by the Operational Groups), in the framework of the SOILLESS GO project, project code (CUP) B97H20000990009. Paper n. 12.

Institutional Review Board Statement: Not applicable.

Informed Consent Statement: Informed consent was obtained from all subjects involved in the study.

Data Availability Statement: The raw data supporting the conclusions of this article will be made available by the authors, without undue reservation.

Conflicts of Interest: The authors declare no conflict of interest.

\section{References}

1. Sánchez-Reinoso, A.D.; Ligarreto-Moreno, G.A.; Restrepo-Díaz, H. Drought-tolerant Common Bush Bean Physiological Parameters as Indicators to Identify Susceptibility. HortScience 2019, 54, 2091-2098. [CrossRef]

2. Folta, K.M.; Childers, K.S. Light as a Growth Regulator: Controlling Plant Biology with Narrow-bandwidth Solid-state Lighting Systems. HortScience 2008, 43, 1957-1964. [CrossRef]

3. Ouzounis, T.; Fretté, X.; Rosenqvist, E.; Ottosen, C.-O. Spectral effects of supplementary lighting on the secondary metabolites in roses, chrysanthemums, and campanulas. J. Plant Physiol. 2014, 171, 1491-1499. [CrossRef] [PubMed]

4. Jeong, S.W.; Park, S.; Jin, J.S.; Seo, O.N.; Kim, G.-S.; Kim, Y.-H.; Bae, H.; Lee, G.; Kim, S.T.; Lee, W.S.; et al. Influences of Four Different Light-Emitting Diode Lights on Flowering and Polyphenol Variations in the Leaves of Chrysanthemum (Chrysanthemum morifolium). J. Agric. Food Chem. 2012, 60, 9793-9800. [CrossRef]

5. Heuvelink, E.; Bakker, M.; Hogendonk, L.; Janse, J.; Kaarsemaker, R.; Maaswinkel, R. Horticultural lighting in the netherlands: New developments. Acta Hortic. 2006, 25-34. [CrossRef]

6. Darko, E.; Heydarizadeh, P.; Schoefs, B.; Sabzalian, M.R. Photosynthesis under artificial light: The shift in primary and secondary metabolism. Philos. Trans. R. Soc. B Biol. Sci. 2014, 369, 20130243. [CrossRef]

7. Polzella, A.; Terzaghi, M.; Trupiano, D.; Baronti, S.; Scippa, G.S.; Chiatante, D.; Montagnoli, A. Morpho-Physiological Responses of Pisum sativum L. to Different Light-Emitting Diode (LED) Light Spectra in Combination with Biochar Amendment. Agronomy 2020, 10, 398. [CrossRef]

8. Goto, E. Plant production in a closed plant factory with artificial lighting. Acta Hortic. 2012, 37-49. [CrossRef]

9. Piovene, C.; Orsini, F.; Bosi, S.; Sanoubar, R.; Bregola, V.; Dinelli, G.; Gianquinto, G.P. Optimal red:blue ratio in led lighting for nutraceutical indoor horticulture. Sci. Hortic. 2015, 193, 202-208. [CrossRef]

10. Paucek, I.; Pennisi, G.; Pistillo, A.; Appolloni, E.; Crepaldi, A.; Calegari, B.; Spinelli, F.; Cellini, A.; Gabarrell, X.; Orsini, F.; et al. Supplementary LED Interlighting Improves Yield and Precocity of Greenhouse Tomatoes in the Mediterranean. Agronomy 2020, 10, 1002. [CrossRef]

11. Palmitessa, O.D.; Leoni, B.; Montesano, F.F.; Serio, F.; Signore, A.; Santamaria, P. Supplementary Far-Red Light Did Not Affect Tomato Plant Growth or Yield under Mediterranean Greenhouse Conditions. Agronomy 2020, 10, 1849. [CrossRef]

12. Chen, X.-L.; Guo, W.-Z.; Xue, X.-Z.; Wang, L.-C.; Qiao, X.-J. Growth and quality responses of 'Green Oak Leaf' lettuce as affected by monochromic or mixed radiation provided by fluorescent lamp (FL) and light-emitting diode (LED). Sci. Hortic. 2014, 172, 168-175. [CrossRef]

13. Li, Q.; Kubota, C. Effects of supplemental light quality on growth and phytochemicals of baby leaf lettuce. Environ. Exp. Bot. 2009, 67, 59-64. [CrossRef]

14. Bian, Z.H.; Yang, Q.C.; Liu, W.K. Effects of light quality on the accumulation of phytochemicals in vegetables produced in controlled environments: A review. J. Sci. Food Agric. 2014, 95, 869-877. [CrossRef] 
15. Kopsell, D.; Sams, C.E.; Morrow, R.C. Blue Wavelengths from LED Lighting Increase Nutritionally Important Metabolites in Specialty Crops. HortScience 2015, 50, 1285-1288. [CrossRef]

16. Qian, H.; Liu, T.; Deng, M.; Miao, H.; Cai, C.; Shen, W.; Wang, Q. Effects of light quality on main health-promoting compounds and antioxidant capacity of Chinese kale sprouts. Food Chem. 2016, 196, 1232-1238. [CrossRef] [PubMed]

17. Samuolienè, G.; Brazaitytè, A.; Jankauskienè, J.; Viršilè, A.; Sirtautas, R.; Novičkovas, A.; Sakalauskienė, S.; Sakalauskaitė, J.; Duchovskis, P. LED irradiance level affects growth and nutritional quality of Brassica microgreens. Open Life Sci. 2013, 8 , 1241-1249. [CrossRef]

18. Brazaitytè, A.; Sakalauskienè, S.; Samuolienè, G.; Jankauskienė, J.; Viršilè, A.; Novičkovas, A.; Sirtautas, R.; Miliauskienė, J.; Vaštakaitè-Kairienè, V.; Dabašinskas, L.; et al. The effects of LED illumination spectra and intensity on carotenoid content in Brassicaceae microgreens. Food Chem. 2015, 173, 600-606. [CrossRef]

19. Meas, S.; Luengwilai, K.; Thongket, T. Enhancing growth and phytochemicals of two amaranth microgreens by LEDs light irradiation. Sci. Hortic. 2020, 265, 109204. [CrossRef]

20. Wojciechowska, R.; Kołton, A.; Długosz-Grochowska, O.; Knop, E. Nitrate content in Valerianella locusta L. plants is affected by supplemental LED lighting. Sci. Hortic. 2016, 211, 179-186. [CrossRef]

21. Samuolienè, G.; Brazaitytè, A.; Sirtautas, R.; Novičkovas, A.; Duchovskis, P. The effect of supplementary led lighting on the antioxidant and nutritional properties of lettuce. Acta Hortic. 2012, 835-841. [CrossRef]

22. Signore, A.; Bell, L.; Santamaria, P.; Wagstaff, C.; Van Labeke, M.-C. Red Light Is Effective in Reducing Nitrate Concentration in Rocket by Increasing Nitrate Reductase Activity, and Contributes to Increased Total Glucosinolates Content. Front. Plant Sci. 2020, 11, 604. [CrossRef] [PubMed]

23. Zhen, S.; van Iersel, M.; Bugbee, B. Why Far-Red Photons Should Be Included in the Definition of Photosynthetic Photons and the Measurement of Horticultural Fixture Efficacy. Front. Plant Sci. 2021, 12. [CrossRef] [PubMed]

24. Izzo, L.G.; Mele, B.H.; Vitale, L.; Vitale, E.; Arena, C. The role of monochromatic red and blue light in tomato early photomorphogenesis and photosynthetic traits. Environ. Exp. Bot. 2020, 179, 104195. [CrossRef]

25. Naznin, M.T.; Lefsrud, M.; Gravel, V.; Azad, O.K. Blue Light added with Red LEDs Enhance Growth Characteristics, Pigments Content, and Antioxidant Capacity in Lettuce, Spinach, Kale, Basil, and Sweet Pepper in a Controlled Environment. Plants 2019, 8, 93. [CrossRef] [PubMed]

26. Kaiser, E.; Ouzounis, T.; Giday, H.; Schipper, R.; Heuvelink, E.; Marcelis, L.F.M. Adding Blue to Red Supplemental Light Increases Biomass and Yield of Greenhouse-Grown Tomatoes, but Only to an Optimum. Front. Plant Sci. 2019, 9, 2002. [CrossRef]

27. Wang, X.Y.; Xu, X.M.; Cui, J. The importance of blue light for leaf area expansion, development of photosynthetic apparatus, and chloroplast ultrastructure of Cucumis sativus grown under weak light. Photosynthetica 2014, 53, 213-222. [CrossRef]

28. Savvas, D.; Gruda, N. Application of soilless culture technologies in the modern greenhouse industry-A review. Eur. J. Hortic. Sci. 2018, 83, 280-293. [CrossRef]

29. Mekbib, F. Yield stability in common bean (Phaseolus vulgaris L.) genotypes. Euphytica 2003, 130, 147-153. [CrossRef]

30. Graham, P.; Ranalli, P. Common bean (Phaseolus vulgaris L.). Field Crop. Res. 1997, 53, 131-146. [CrossRef]

31. El Youssfi, L.; Choukr-Allah, R.; Santamaria, P.; Montesano, F.F. Soilless Closed Cycle Production Of Green Bean (Phaseolus vulgaris L.) Using Subirrigation: Effects On Yield, Fruit Quality, Substrate And Nutrient Solution Parameters. Acta Hortic. 2012, 383-390. [CrossRef]

32. Palmitessa, O.; Pantaleo, M.; Santamaria, P. Applications and Development of LEDs as Supplementary Lighting for Tomato at Different Latitudes. Agronomy 2021, 11, 835. [CrossRef]

33. Leser, S. The 2013 FAO report on dietary protein quality evaluation in human nutrition: Recommendations and implications. Nutr. Bull. 2013, 38, 421-428. [CrossRef]

34. Kusumah, S.H.; Andoyo, R.; Rialita, T. Isolation and Characterization of Red Bean and Green Bean Protein using the Extraction Method and Isoelectric pH. SciMedicine J. 2020, 2, 77-85. [CrossRef]

35. Sancarlos, A.; Cameron, M.; Abel, A.; Cueto, E.; Duval, J.L.; Chinesta, F. From ROM of Electrochemistry to AI-Based Battery Digital and Hybrid Twin; Springer: Berlin/Heidelberg, Germany, 2021; Volume 28, ISBN 0123456789.

36. Johnson, R.E.; Kong, Y.; Zheng, Y. Elongation growth mediated by blue light varies with light intensities and plant species: A comparison with red light in arugula and mustard seedlings. Environ. Exp. Bot. 2019, 169, 103898. [CrossRef]

37. Huché-Thélier, L.; Crespel, L.; Le Gourrierec, J.; Morel, P.; Sakr, S.; Leduc, N. Light signaling and plant responses to blue and UV radiations-Perspectives for applications in horticulture. Environ. Exp. Bot. 2016, 121, 22-38. [CrossRef]

38. Renna, M.; D'Imperio, M.; Gonnella, M.; Parente, A.; Santamaria, P.; Serio, F. Barattiere: An Italian Local Variety of Cucumis melo L. with Quality Traits between Melon and Cucumber. Plants 2020, 9, 578. [CrossRef] [PubMed]

39. Pathare, P.; Opara, U.L.; Al-Said, F.A.-J. Colour Measurement and Analysis in Fresh and Processed Foods: A Review. Food Bioprocess Technol. 2012, 6, 36-60. [CrossRef]

40. Paciulli, M.; Palermo, M.; Chiavaro, E.; Pellegrini, N. Chlorophylls and Colour Changes in Cooked Vegetables. In Fruit and Vegetable Phytochemicals: Chemistry and Human Health; Yahia, E.M., Ed.; John Wiley \& Sons Ltd: Hoboken, NJ, USA, 2018; pp. 703-719; ISBN 9781119158042.

41. Pola, W.; Sugaya, S.; Photchanachai, S. Color Development and Phytochemical Changes in Mature Green Chili (Capsicum annuиm L.) Exposed to Red and Blue Light-Emitting Diodes. J. Agric. Food Chem. 2019, 68, 59-66. [CrossRef] 
42. Hogewoning, S.; Trouwborst, G.; Maljaars, H.; Poorter, H.; van Ieperen, W.; Harbinson, J. Blue light dose-responses of leaf photosynthesis, morphology, and chemical composition of Cucumis sativus grown under different combinations of red and blue light. J. Exp. Bot. 2010, 61, 3107-3117. [CrossRef]

43. Xu, Z.; Zhou, G. Responses of leaf stomatal density to water status and its relationship with photosynthesis in a grass. J. Exp. Bot. 2008, 59, 3317-3325. [CrossRef] [PubMed]

44. Von Caemmerer, S.; Evans, J. Temperature responses of mesophyll conductance differ greatly between species. Plant Cell Environ. 2014, 38, 629-637. [CrossRef] [PubMed]

45. Murchie, E.; Lawson, T. Chlorophyll fluorescence analysis: A guide to good practice and understanding some new applications. J. Exp. Bot. 2013, 64, 3983-3998. [CrossRef] [PubMed]

46. Lysenko, V.; Guo, Y.; Kosolapov, A.; Usova, E.; Varduny, T.; Krasnov, V. Polychromatic Fourier-PAM fluorometry and hyperspectral analysis of chlorophyll fluorescence from Phaseolus vulgaris leaves: Effects of green light. Inf. Process. Agric. 2019, 7, $204-211$. [CrossRef] 